\title{
Social Science Information Service in Poland: an attempt to present the state of art
}

\begin{abstract}
The political, economic and educational transformation taking place in Poland for several years has resulted in, among other things, ever-growing interest in social sciences and, consequently, in growing demand for specialized information in that field.
\end{abstract}

This paper tries to give answers to the following questions:

- Can we observe any direct relation between transformation and growing demand for social science information service? If so,

- What kind of information is searched for most frequently?

- Are social science information services ready to supply users with necessary information?

A questionnaire has been sent to a number of representative scientific libraries. Special regard has been given to the Bureau of Polish Official Statistics. The feedback of responding libraries has been thoroughly analysed and results presented in the paper.

In the paper an attempt is made to describe a condition of contemporary social science information service in Poland. A brief characterization of information sources, staff and categories of users is given.

\section{Introduction}

Great changes taking place in Poland in the last decade due to political, economic and educational transformation has resulted in, among other things, ever-growing interest in social sciences and ever-growing demand for specialized information in that field. The number of students in social sciences doubled within the last six years, and new specialized studies have been launched. The process of transformation has drawn the attention of many research workers who examine and describe new phenomena. That process has been the object of interest for the authors of this paper as well, but only those aspects of it which are connected with information supply, take place in libraries and have influenced the social sciences information services activity.

This paper tries to give answers to the following questions:

- Can we observe any direct relation between transformation and growing demand for social science information services?

- What kind of information is searched for most frequently?

- Are social science information services ready to supply users with necessary information?

\section{Survey Process}

A questionnaire has been sent to 40 representative scientific libraries, including libraries of major Polish universities, higher education institutions (of university level), governmental institutions, scientific institutes, and municipal libraries. The questionnaire consisted of four main sections: social science information services general information and introductory remarks; social science information services users; sources and forms of services; and information searched for most frequently.

Responses have been received from 32 libraries, however two questionnaires could not be taken into consideration because only one third of questions had been answered. Five libraries have informed us that they do not run specialized social science information services, but inquiries relating to that topic may be addressed to their information desks. There has been no answer from three libraries. In all, feedback from 30 libraries has been analysed and an attempt has been made to present a condition of contemporary social sciences information service in Poland. A brief characterization of information sources, staff and categories of users has been given. Special regard has been given to Polish Central Statistical Office.

In this context let us draw your attention to one fact. The ranking of the best state higher education institutions (of university level) reported recently in two outstanding Polish papers ("Rzeczpospolita", "Perspektywy"), included 75 schools, of which 45 run polytechnics, physical training 
and medical studies. In view of the above, the sample (collected material) can be treated as representative.

The analysis of feedback allows us to give a general description of contemporary social science information services in Poland. The collected material is discussed briefly in the following sections:

- Social science information services launching

- Staff

- Categories of users

- Facilities and information sources

- Forms of services

- Information searched for most frequently

- Central Statistical Office

- Conclusions

\section{Social Sciences Information Services Launching} In Poland, the first social science information services started their activities in the 1920s. The majority (50\%) of them, however, began their work after the Second World War and during the period 1960-1985. All respondents unanimously observed a radical increase in demand for social science information services after 1990, when big political, economic and educational changes began. This ongoing process of transformation, and preparation made by Poland to integrate with the European Community, allow us to expect that interest in social science information services will continue.

\section{Staff}

According to received responses, all social science information services staff are well prepared to perform their duties. They have master degrees corresponding with their occupations, i.e., in the fields of economics, sociology, political science, psychology, pedagogic, library and information sciences. Apart from that, 50\% of examined staff attended special courses and training. They have knowledge of how to access and navigate databases (LAN, MAN, www). They know how to download, print and operate with applications packages. They are always ready to supply users with necessary information, give advice and locate accessible data on a requested topic. Users expect social science information services staff to be competent, and so they are.

\section{Categories of Users}

Permanent visitors of social science information services are individuals, as well as institutions and organizations. Individuals include students, research workers, persons preparing dissertations, teachers, journalists, managers, and entrepreneurs. The majority of individual users are students, teachers and research workers. Institutions and organizations include governmental institutions, local government (self-government), educational organizations, and various foundations. Moreover, any person who seeks information or advice related to social science information services is welcome.

\section{Facilities and Information Resources}

All surveyed social science information services have at their disposal, reference collections consisting of printed materials such as encyclopaedias, dictionaries, bibliographies, and subject-oriented monographs, and materials issued by the Central Statistical Office. Since $1993 / 94$, all social science information services have been able to provide access to information sources in electronic form and to the Internet. They possess a wide range of Polish and foreign databases on diskettes and CDs, and online access to some foreign databases, mostly free of charge, issued by the European Union (e.g., EUR-Lex, CELEX, EUROPA).

The most frequently quoted foreign databases subscribed to by libraries and the percentage of social science information services that have them are:

- WILSON Social Sciences Abstracts (30\%)

- ERIC on Silver Platter $(25 \%)$

- Social Sciences Citation Index with Abstracts (15\%)

About $35 \%$ of social science information services elaborate their own databases. Those databases refer to socioeconomic problems, European law, and education (e.g., "Social Sciences" in two languages (Polish, English) and "Economics on-line" issued quarterly by the Main Library of Cracow University of Economics).

\section{Forms of Services}

Social science information services staffs offer a wide range of information dealing with socio-economic problems. They are capable to provide users with necessary information, give advice, and locate accessible data on the topic of interest. The forms of information delivery are different, but most commonly quoted are the following:

- direct inquires on the spot at information desk

- by telephone

- via email

- on-line services (topic-oriented searching)

- provision of data to individuals using desktop PCs (exceptionally)

- downloading

At the user's request, social science information services officers elaborate subject-oriented bibliographies and statistical data, and prepare printed extracts from databases. Access to databases and Internet for parent institution users is free of charge but limited in time. 
Information Searched for Most Frequently

The very term "social science" designates the boundaries of information for which one might search. "Social sciences" are meant to be a set of disciplines which deal with aspects of human society. It is commonly understood that "social sciences" include, first of all, economics, sociology and political sciences. The received responses allow us to identify precisely what kind of information is needed in Poland now. We can identify the following topics (problems) which have been the object of special interest to social science information services users, and the information relating to these subjects that has been searched for most frequently:

- quality of life

- relation of economics to social values

- economics of the elderly

- child care

- unemployment

- demographic trends and forecasts

- social reforms (of education, health, social insur ance and pensions)

- state and local government

- taxation

- education

- European Union

- integration with EU

- European law

- small business

- marketing

- analysis of social consequences of transformation

- all kinds of statistical data

In summary, information relating to socio-economic problems, reforms, integration with the European Union and statistical data are the hot subjects of interest to Polish social science information services users.

\section{Central Statistical Office}

\section{Polish Statistical System}

The statistical system in Poland has been functioning since 1789 , when the nationwide census and property state was carried out. The first in Poland and one of the earliest Statistical Offices in Europe was founded in 1810. The Central Statistical Office (CSO), which nowadays is the central statistical institution in the state, was created in 1918. It supervises the activities of the regional statistical offices. Next year it will celebrate its $200^{\text {th }}$ anniversary.

The contemporary statistical system in Poland consists of CSO and 17 regional statistical offices collecting and processing various data, the statistical information system, classifications, registers, and the publication system. Each calendar year, CSO announces the Statistical Survey Programme. The schedule for the year 2001, included 15 main categories, such as the population and demographic processes, labour market, wages and social insurance, education, science and the technical progress.

\section{CSO Information System}

The statistical information system is conducted by both the CSO and the regional statistical offices, always using the nationwide data. Individual and personal data collected during statistical surveys are confidential and subject to special protections. They are used exclusively for elaborations and analysis carried out by the official statistics.

The legal basis of Polish official statistics is the Official Statistics Act of 1995. It guarantees indiscriminatory, equal, and simultaneous access to statistical data for all users. The CSO system divides the information users into three groups, whose information inquiries are responded to by two units: Data Dissemination Division (DDD) and Information and Publication Bureau (IPB). DDD serves authorities and government administration, local government and international organizations. The services are free of charge. IPB serves mass media and other users. The detailed information and analyses are charged. It is also possible to obtain information by phone from the Bulletin Board System (BBS), Automatical Statistical Information and the Central Statistical Informatory.

\section{CSO Library}

The CSO Library - The Central Statistical Library - was founded in 1918. The book collection is the oldest and the largest special collection in Poland. It contains all the CSO publications from the beginning of its origin, as well as more important publications of the local statistical offices in Poland and a collection of current and retrospective worldwide statistical publications. The Library collects the statistical yearbooks from about 150 countries and those of international organizations. The serials collection contains mainly the current journals dealing chiefly with statistics and demography.

\section{The CSO Publication System}

The data collected and elaborated by CSO divisions are issued in printed and electronic form. We may distinguish different publication groups: statistical yearbooks, book series, bulletins and periodicals. Some of these publications can be accessed directly from the CSO web site at www.stat.gov.p], as shown below.

Special regard should be given to book series published by CSO divisions, such as:

- Studia i analizy statystyczne (Statistical surveys and analysis)

- Studia i Prace. Z Prac Zakładu Badań Statystyczno-Ekonomicznych GUS i Polskiej Akademii Nauk (Studies and elaborations of Research Centre for 

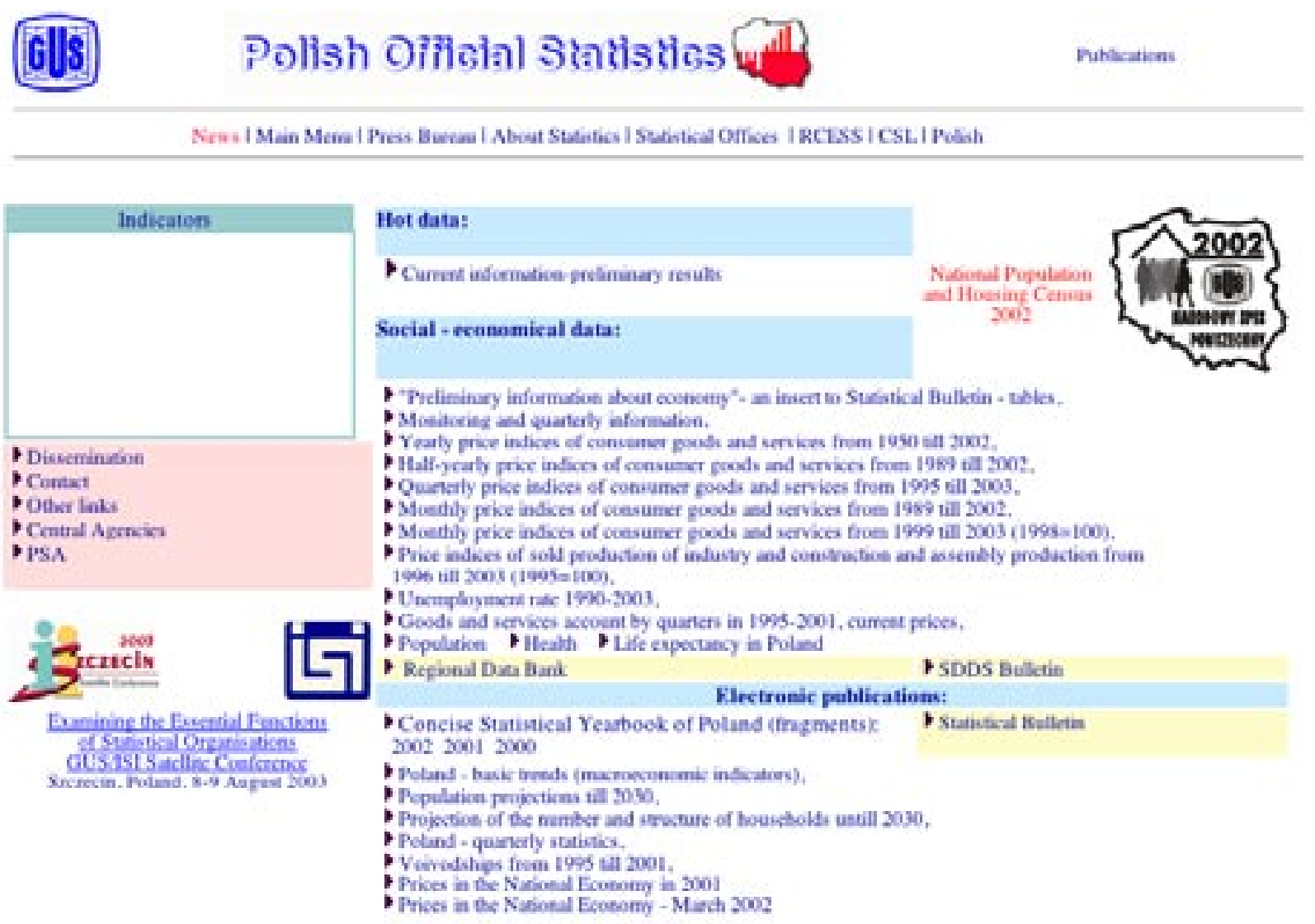

Economic and Statistical Studies of the Central Statistical Office and the Polish Academy of Sciences)

- Informacje i opracowania statystyczne (Statistical information and elaborations)

- Materiały źródłowe (Statistical sources)

- Biblioteka "Wiadomości Statystycznych"

("Statistical News" Library)

\section{CSO Information Services}

CSO offers processing and analysis of statistical data gathered within the confines of the annual Statistical Survey Program of Official Statistics. Results of the surveys are disseminated in the form of CSO publications as well as surveys ordered by users. Orders demanding distinct calculation and elaborations of statistical data are charged according to the price list. Usage of the Local Data Bank is free in the scope of topics specific to the CSO regulations; access to the other data is charged. Access to other on-line statistical sources (e.g., "Information about social-economic condition" or "Poland - main macroeconomic indicators") is charged.

\section{Conclusions}

1. A direct correlation has been observed between transformation taking place in Poland since 1990, and ever-growing demand for social sciences information services.

2. The interest in social science information services has intensified within last few years in view of the expected integration with the EU and reforms implementations.

3. Information relating to socio-economic problems, reforms, integration with the EU and statistical data are searched most frequently.

4. Social science information services staff have satisfactory qualifications to perform their duties and meet the demands made upon them. However, training and practice in well-organized specialized information centres could contribute to improvement of staff skills. 
5. The main obstacle in further development of social science information services is scarcity of funding to support the high costs of necessary equipment and foreign database subscriptions.

* Paper presented at the IASSIST Conference, May 2001, in Amsterdam, The Netherlands. Teresa Wildhardt, Cracow Pedagogical University, Main Library, Poland (sbwildha@cyf-kr.edu.pl) and Anna Sokołowska-Gogut, Cracow University of Economics, Main Library, Poland (gogut@bibl.ae.krakow.pl). 